Rev. Adam Olszewski

ORCID: 0000000330697518

Uniwersytet Papieski Jana Pawła II w Krakowie

Copernicus Center

\title{
Linda problem - the tame solution in question
}

\section{Short Essential Reminder on The Linda Problem}

I will now present the work of Kahneman and Tversky (abbreviation: KT) in a nutshell to make the present work sufficient on its own. The so-called Linda's experiment was carried out by $\mathrm{KT}$ and consisted in the following short description of a woman named Linda:

Linda is thirty-one years old, single, outspoken, and very bright. She majored in philosophy. As a student, she was deeply concerned with issues of discrimination and social justice, and also participated in anti-nuclear demonstrations. [...] The subjects were asked which of the following two propositions is more probable. 'Linda is a bank teller'. ( $\mathrm{T}$ ) or 'Linda is a bank teller and is active in the feminist movement' $(\mathrm{T} \wedge \mathrm{F})^{1}$.

The majority of the surveyed subjects indicated as more probable the conjunction of sentences, more probable than one of its conjuncts. That is, they considered that $\mathrm{P}(\mathrm{T})<\mathrm{P}(\mathrm{T} \wedge \mathrm{F})$, contrary to the axioms of the probability calculus, which states, in this case, that $\mathrm{P}(\mathrm{T} \wedge \mathrm{F}) \leq \mathrm{P}(\mathrm{T})$. This became, among

1 A. Tversky, D. Kahneman, Extensional versus Intuitive Reasoning: The Conjunction Fallacy in Probability Judgment, "Psychological Review" 90 (1983), p. 297. 
other things, the basis for the creation of the concept of representativeness heuristics by the $\mathrm{KT}$.

\section{Implications of $\mathrm{KT}$ Solution}

KT solved Linda's problem using a ready-made concept of heuristics, which they developed creatively to fit. Their concept met, one might even say, with an enthusiastic response from scientists all over the world. It continues to this day, just look at the quotability of works on Linda's problem in world literature. There has also been a slight criticism of this solution. ${ }^{2}$ In one place of their work, KT s briefly describe their experiment from the Linda series, where they asked the participants who were presented with eight sentences about Linda, to sort out these sentences according to "the degree to which [...] Linda resembles the typical member of that class." ${ }^{3}$ The evaluations ranged from 1 (very unlike) to 9 (extremely likely) and the results were as follows: " $t$ the percentage of respondents who displayed the predicted order $([\ldots] \mathrm{F}>\mathrm{T} \wedge \mathrm{F}>\mathrm{T}$ for Linda) were $[\ldots]$ 85\% [...]." 4 The sentence indicated by к $\mathrm{T}$ will be understood for our purposes as an abbreviation of the conjunction of sentences of the form: $(\mathrm{T}<(\mathrm{T} \wedge \mathrm{F})) \wedge((\mathrm{T} \wedge \mathrm{F})<\mathrm{F}){ }^{5}$ Then, in accordance with the axioms of the probability calculus, we must recognize that the probability of ordering sentences

2 Cf. R. Moro, On the Nature of the Conjunction Fallacy, "Synthese" 171 (2009), for the current state of research on Linda's problem. Compare in the literature the following works: P. Maguire, P. Moser, R. Maguire, M. T. Keane, Why the Conjunction Effect Is Rarely a Fallacy: How Learning Influences Uncertainty and the Conjunction Rule, "Frontiers in Psychology" 9 (2018) no. 1011; and K. Tentori, N. Bonini, D. Osherson, The Conjunction Fallacy: a Misunderstanding about Conjunction?, "Cognitive Science" 28 (2004); which contain similar considerations to our own, though different.

A. Tversky, D. Kahneman, Extensional versus Intuitive Reasoning: The Conjunction Fallacy in Probability Judgment, "Psychological Review" 90 (1983), p. 297.

4 A. Tversky, D. Kahneman, Extensional versus Intuitive Reasoning: The Conjunction Fallacy in Probability Judgment, "Psychological Review" 90 (1983), p. 297. It should be noted that the sentence $\mathrm{T}<(\mathrm{T} \wedge \mathrm{F})<\mathrm{F}$, being the result of the order determined by the respondents used by KTs in reporting their research, is at least ambiguous because it can be understood as expressing a three-termed or two-termed relation between the constituent sentences. The three-termed relation cannot necessarily be reduced to a binary relation. An example of such an impossibility is the theory of 'lying in-between' in geometry, based on a three-termed relation.

5 The inscription $(\mathrm{A}<\mathrm{B})$ will continue to be ambiguous, but I do not think that this will lead to misunderstanding, since the context will always allow the meaning to be clarified. In the first meaning $(\mathrm{A}<\mathrm{B})$, it will mean that the sentence $\mathrm{A}$ is in the ordering relation $<$ with the sentence 
$\mathrm{T}<(\mathrm{T} \wedge \mathrm{F})$ has been chosen by at least $85 \%$ of the respondents, and, what is even more important for us, similarly occurs for the second pair of sentences that are of interest to us, namely: $(\mathrm{T} \wedge \mathrm{F})<\mathrm{F}$. This result announced by $\mathrm{KT}$ is interesting in itself, and it is to this that our work will continue.

\section{The Structure and Philosophical Motivation of Our Argument}

Now, I will move on to the essential part of my argument against the concept proposed by кт. My argument will have the structure of indirect reasoning. Let us assume, therefore, that all of KT's interpretations, both the partial experiments (the experiments accompanying the main experiment) and the main experiment, as well as the experimental results, are correct. Let us also assume that their concept of heuristics is correct. ${ }^{6}$ I will try to draw a conclusion from these mentioned assumptions, and confront it with empirical research. Schematically, it looks as follows: if we mark all the assumptions and partial results with the letter $\mathrm{Z}$, then: $\mathrm{Z} \Rightarrow \mathrm{H}_{0}$, where $\mathrm{H}_{\mathrm{o}}$ will be the mentioned consequence, which I think will show the results of my experiments. The content of $\mathrm{H}_{\mathrm{o}}$ will be provided in detail. The statement $\mathrm{H}_{\circ}$ which is the consequence of $\mathrm{Z}$, will prove to be implausible. It is the negation $\neg \mathrm{H}_{\mathrm{o}}$ which will prove to be plausible. The implausibility of $\mathrm{H}_{\mathrm{o}}$ will lead us to reject $\mathrm{Z}$ and adopt the negation $\neg \mathrm{Z}$. For a better understanding of my argumentation, let us present its formal structure:

1. $\mathrm{Z} \equiv\left(\mathrm{Z}_{\mathrm{I}} \wedge \ldots \wedge \mathrm{Z}_{\mathrm{n}}\right)$,

2. $\mathrm{Z} \Rightarrow \mathrm{H}_{\mathrm{o}}$

3. $\neg \mathrm{H}_{\mathrm{o}}$,

4. Therefore: $\neg \mathrm{Z} \equiv\left(\neg \mathrm{Z}_{\mathrm{I}} \vee \ldots \vee \neg \mathrm{Z}_{\mathrm{n}}\right)$; where $\mathrm{Z}_{\mathrm{i}}(1 \leq \mathrm{i} \leq \mathrm{n})$.

In the second paragraph above, I quoted KT's study, which showed that at least $85 \%$ of the studied population selected the following relations between the sentences $\mathrm{T}, \mathrm{F}$ and $(\mathrm{T} \wedge \mathrm{F}):(\mathrm{T}<(\mathrm{T} \wedge \mathrm{F}))$ and $((\mathrm{T} \wedge \mathrm{F})<\mathrm{F})$. When $\mathrm{KT}$ repeated these studies (in a slightly different way), this strong relationship

B. In the second meaning, that the probability of the occurrence $\mathrm{A}$ is less than the probability of the occurrence of $B$.

6 Heuristics for KTs are properly simplified methods of inference, the use of which usually allows correct conclusions to be drawn.

7 This means that at least one $\mathrm{Zi}$ of the $\mathrm{Z}$ members (conjuncts) is false. Please remember what $\mathrm{Z}$ means. 
$(\mathrm{T}<(\mathrm{T} \wedge \mathrm{F}))$ was invariably confirmed. ${ }^{8}$ From what we find in $\mathrm{KT}$ 's article, there is no information pertaining to the investigation of the sentence $((\mathrm{T} \wedge \mathrm{F})<\mathrm{F})$.

However, there is a certain relation and similarity between these two inequalities. In the case of a sentence $((\mathrm{T} \wedge \mathrm{F})<\mathrm{F})$ we have, as in the sentence $(\mathrm{T}<(\mathrm{T} \wedge \mathrm{F}))$, a comparison of a the conjunction $(\mathrm{T} \wedge \mathrm{F})$ with one of its conjuncts ( $\mathrm{T}$ or $\mathrm{F})$. However, in the case of a sentence $((\mathrm{T} \wedge \mathrm{F})<\mathrm{F})$, unlike sentence $(\mathrm{T}<(\mathrm{T} \wedge \mathrm{F}))$, no conjunction fallacy occurs.

Specifically, it should be said that this gives rise to the questioning of the general term conjunction fallacy, as it concerns only such a particular conjunction of sentences, one of which is burdened with heuristics-according to the terminology of $\mathrm{KT}$. If the sentence $\mathrm{F}$ was not burdened with heuristics, then, if the subjects were to determine the relation of a minority of the probability of occurrence of relevant events, the result would most probably be in accordance with the principles of the probability calculus. KT mention so far such a study and this result (p. 305), where Linda was characterized as a "31-years-old woman." That is, the result was exactly the same as in the case of a sentence $((T \wedge F)<F)$, which means that no conjunction fallacy occurred.

However, taking into account the results of KT's surveys as mentioned at the end of the third paragraph of this article, it appears that the same percentage of respondents voted for both sentences under consideration. This, however, must be surprising, since the question arises as to why the percentage of voters in favour $(T<(T \wedge F))$ is so high, or why the percentage of voters in favour $((T \wedge F)$ $<\mathrm{F})$ is so low. Let's look at the matter a little further and consider the sentences $\mathrm{T}, \mathrm{F}$ and $\mathrm{T} \wedge \mathrm{F}$. In accordance with the rules of the probability calculus only, we should order them in terms of the probability of occurrence of the corresponding events in the following way: $((\mathrm{T} \wedge \mathrm{F}) \leq \mathrm{T})$ and $((\mathrm{T} \wedge \mathrm{F}) \leq \mathrm{F})$, and assume that the percentage of respondents attributing the above dependencies to them was the same for both sentences. This was N\%, where $\mathrm{N}$ could be close to 100. Such a situation occurs in studies if they are not preceded by the introduction of Linda's description. ${ }^{9}$ However, after reading the full description of Linda, the situation has changed. One change worried $\mathrm{kT}$ because of an inequality

The methods used to obtain certain results do not differ in essence, i.e., they consistently show the superiority of the conjunction over one of its components.

A. Tversky, D. Kahneman, Extensional versus Intuitive Reasoning: The Conjunction Fallacy in Probability Judgment, "Psychological Review" 90 (1983). 
$(\mathrm{T}<(\mathrm{T} \wedge \mathrm{F})),{ }^{10}$ contrary to the relevant axiom of probability theory. More precisely, $85 \%$ of the population considered that $(\mathrm{T}<(\mathrm{T} \wedge \mathrm{F}))$ occurred. This change required an explanation of what the concept of heuristics, in particular heuristic representativeness, was intended to serve. At this point, the natural question arises whether something has changed in the case of a sentence $((\mathrm{T} \wedge \mathrm{F})<\mathrm{F}){ }^{11}$

\section{Description of Surveys $\mathrm{N}^{\circ} .1$ and $\mathrm{N}^{\circ} .2$}

It seems that KTs took the view that nothing would change after adding Linda's description in the assessment of the relation of probability in the case of $((\mathrm{T} \wedge \mathrm{F})$ $<\mathrm{F}$ ), as they did not, in this view, deal with it any more, as opposed to the earlier. This sentence should have a high probability even if only because it is (almost) a replacement for the axiom of the probability calculus, and in addition, if you include a full description of Linda, then hypothetically the probability should even increase. In order to check this, two experiments have been carried out, the brief descriptions of which we quote here.

Survey_No.1. It was performed at the beginning of 2017 on a group of 161 students aged 19-23 years. ${ }^{12}$ These were students of journalism and theology at UPJP 2 who did not pass special courses in logic, statistics or probability calculus. The percentage distribution of sexes was approximate: $40 \%$ of men and $60 \%$ of women. ${ }^{13} \mathrm{~A}$ full description of Linda is given, exactly as in the original KT experiment. Respondents were then presented with two sentences: 'Linda is active in the feminist movement' $(\mathrm{F})$ and the sentence 'Linda is a bank teller and active in the feminist movement' $(\mathrm{T} \wedge \mathrm{F})$. As a result of the survey, $70.8 \%$ (114 persons) of students chose the conjunction as less likely than the F sentence, while the opposite was chosen by $29.2 \%$ (47 persons) of respondents. ${ }^{14}$

${ }^{10}$ I would like to remind you that, in this context, the inscription $(T<(T \wedge F))$ should be understood as the probability of the event described in the sentence $\mathrm{T}$, which is smaller than the probability of the event described by the conjunction $(T \wedge F)$ of sentences.

${ }_{11}$ The reader may have a problem with the relation $\leq$ appearing once, and another time in the same context, the relation <. The first relation, i.e., which occurs in axioms of the probability calculus, allows the identity of probabilities, which is only rarely the case in our considerations.

${ }_{12}$ Especially the first of these experiments was carried out without noticing some data from the point of view of data methodology.

${ }_{13}$ The surveys were conducted in Polish for understandable reasons.

${ }^{14}$ Referring to earlier considerations, after performing the experiment, I asked one of the students why he assessed the probability of a conjunction being higher than one part of it. He answered that, if Linda became a feminist, she had to work to make a living from it. 
Survey_No $\mathrm{N}^{\circ}$.2. It was made on 29.05.2019, on a group of 73 people (64 women $-86.7 \%$; 9 men $-12.3 \%$ ), aged 20-25 years, who are students of the first year of full-time pedagogy at the University of Łódź. Respondents did not attend the course of logic, statistics or probability calculus. The result of the experiment was as follows: $71.2 \%$ (52 persons) chose the conjunction of sentences as less likely than the F. the opposite indicated by $28.8 \%$ ( 21 persons) of students.

\section{Conclusions Drawn from The Tests Carried Out}

Before the experiments, a zero hypothesis $\mathrm{H}_{\mathrm{o}}$ was put forward, which, as indicated earlier, was a conclusion of the sentences adopted by кт, forming the conjunction $\mathrm{Z}$.

$\left(\mathrm{H}_{\mathrm{o}}\right)$ (Zero hypothesis) At least $85 \%$ of the respondents will choose the sentence $\mathrm{F}$ as more likely than the sentence $(\mathrm{T} \wedge \mathrm{F})$, and the opposite consequently will be selected at most by $15 \%$ of the respondents. Therefore, we assume that our research will confirm the results indicated by кт.

The quadrant compliance chi-square test for the survey $\mathrm{N}^{\circ}$.1. a score of $\chi^{2}$ $=25.4,(\mathrm{df}=1, \mathrm{p}<0.001)$; while for the survey $\mathrm{N}^{0} .2 \cdot \chi^{2}=10.61,(\mathrm{df}=1, \mathrm{p}<0.005)$. According to normal criteria, such a results lead to the rejection of the zero hypothesis, which is surprising if we compare it with the results of surveys cited by кт. Although these surveys differ in the way they are carried out, of course, there is a problem here, which requires more detailed research. I call $\mathrm{H}_{\mathrm{o}}$ to be a paradoxical sentence, ${ }^{15}$ because it can be deduced from the set $Z$, i.e., the entire research and $\mathrm{KT}$ 's hypotheses presented in Linda's problem and at the same time, it was refuted by my presented research.

It should be noted that in contrast to KT, on the basis of the arguments similar to my previous study, ${ }^{16}$ it can be better justified why there is such a percentage ratio between sentences $(\mathrm{T} \wedge \mathrm{F})$ and $\mathrm{F}$, i.e., in a similar percentage relation to that which appeared in the given our empirical study. This is a reconstruction of the argument:

1. $\mathrm{P}(\neg \mathrm{T} \wedge \mathrm{F}) \leq \mathrm{P}(\mathrm{F})$; from substitution into an axiom of probability,

2. $\mathrm{P}(\mathrm{T})<\mathrm{P}(\neg \mathrm{T})$; a baseline observation,

${ }^{15}$ I am talking about the paradoxical character of $\mathrm{H}_{\mathrm{o}}$ on the basis of the etymology of the term coming from the para doxi $\zeta$ i.e., contrary to people's mindsets or common opinions.

${ }_{16}$ A. Olszewski, A Few Comments on the Linda Problem, “Organon F” 24 (2017), p. 184-195. 
3. $\mathrm{P}_{\mathrm{T}}(\mathrm{F})=\mathrm{P} \neg_{\mathrm{T}}(\mathrm{F})$; a baseline observation for the conditional probability $\mathrm{P}_{\mathrm{T}}{ }^{17}$ 4. $\mathrm{P}(\mathrm{T} \wedge \mathrm{F})<\mathrm{P}(\neg \mathrm{T} \wedge \mathrm{F})$; both sides conjoin to 2 . and independence of sentences,

5. $\mathrm{P}(\mathrm{T} \wedge \mathrm{F})<\mathrm{P}(\mathrm{F}) ;^{18}$ from transitivity of $<$,

6. $\mathrm{P}_{\mathrm{C}}(\mathrm{T} \wedge \mathrm{F})<\mathrm{P}_{\mathrm{C}}(\mathrm{F})$; from 4 . and conditional probability $\left(\mathrm{P}_{\mathrm{C}}\right)$, where $\mathrm{C}$ is the conjuction of sentences forming the description of Linda.

The last formulae from lines 4 . and 5. give a sought-after inequality. However, what is important for our considerations, if we understand implicitly $\mathrm{F}$ as $(\mathrm{F} \wedge \neg \mathrm{T})$, as in the previous article, ${ }^{19}$ the probability of $\mathrm{P}(\mathrm{F} \wedge \neg \mathrm{T})$ is indeed smaller than $\mathrm{P}(\mathrm{F})$, and larger than $\mathrm{P}(\mathrm{F} \wedge \mathrm{T})$, which would fit well with the results of our surveys.

\section{Summary and Critical Comments}

To sum up the above considerations, we can say that the concept of heuristics built by KT partially on the basis of Linda's survey is, firstly, (a) too hasty and, secondly, (b) contradictory, in some weak sense. As far as (a) is concerned, the introduction of heuristics, which were supposed to explain the results of Linda's survey, may not be necessary, as rational human skills explain and solve sufficiently the problems posed. Perhaps someone should think about it and try to interpret Linda's survey differently, for example by testing the hypothesis that some other strictly rational factor is responsible for the outcome of the survey. This possibility is presented in my both studies, although my comments are rather scattered and casual. The second point (b) speaks of a so-called weak contradiction. This is not a technical term, but describes the situation with the Linda issue. KT focused their attention on the controversial sentence $\mathrm{T}<$ $(\mathrm{T} \wedge \mathrm{F})$, but they did not take into account what is happening with the second sentence, namely $(\mathrm{T} \wedge \mathrm{F})<\mathrm{F}$. In the latter there are also problems. The situation is that, if the degree of probability attributed to the components of the controversial sentence gives an assumpt to create heuristics, then the attribution of the second sentence weakly contradicts the heuristics. More specifically,

${ }_{17}$ This premise assumes that the collection of feminists is evenly distributed in the population, due to the bank's female employees. This means that, statistically, there are as many feminists among bank employees as among women who are not bank employees.

${ }_{18}$ I try to be strict here. The formula from line 4. is not a substitution into the axiom, because there is a relation symbol $<$ and not the relation in it. That is why this formula requires proof.

19 A. Olszewski, A Few Comments on the Linda Problem, "Organon F" 24 (2017), p. 184-195. 
if heuristics solve the Linda problem-that associated with the first sentencethen, if we apply them to the problem with the second sentence, we will obtain a paradoxical conclusion that stands opposed to common opinion.

\section{Abstract}

After a brief reminder of the, so called, Linda problem and its solution by Kahneman \& Tversky (кT) (the tame solution), I point out the implications of the solution adopted by the KTs. Among these implications, I emphasize the importance of the relation of probability between the sentences: 'Linda is active in a feminist movement' (F) and 'Linda is a bank teller and active in a feminist movement' $(\mathrm{T} \wedge \mathrm{F})$; while in $\mathrm{KT}$ 's paper the main emphasis was put on considering the relationship between the probability of sentences: 'Linda is a bank teller' ( $\mathrm{T}$ ) and 'Linda is a bank teller and active in a feminist movement' $(\mathrm{T} \wedge \mathrm{F})$. I offer a critical argument against the zero hypothesis $\mathrm{H}_{\mathrm{o}}$ that 'at least $85 \%$ of the respondents will choose the sentence $\mathrm{F}$ as more likely than the sentence $(T \wedge F)$, and the opposite consequently will be selected at most by $15 \%$ of the respondents;' being drawn from the assumptions made by Kahneman and Tversky. This hypothesis will be further partially refuted by means of results from the surveys $\mathrm{N}^{\circ}$.1. and $\mathrm{N}^{\circ} .2$. Then the reasoning supporting the result of surveys is presented and finally critical conclusions will be derived.

\section{KEYWORDS}

conjunction, heuristics, interpretations, Kahneman\&Tversky experiment, Linda problem, probability

\section{ABstrakT}

\section{Problem Lindy - zakwestionowanie oswojonego rozwiązania}

Po krótkim przypomnieniu, na czym polega tzw. problem Lindy oraz jego rozwiązania przez Kahnemana i Tversky'ego (Кт), wskazuję na implikacje ich rozwiązania tego problemu. Pośród tych implikacji podkreślam znaczenie relacji pomiędzy prawdopodobieństwami przypisanymi zdaniom: „Linda is active in a feminist movement” (F) oraz „Linda is a bank teller and active in a feminist movement” $(\mathrm{T} \wedge \mathrm{F})$; Kahneman i Tversky kładli główny nacisk na relację pomiędzy prawdopodobieństwami przypisanymi zdaniom: „Linda is a bank teller” (T) and „Linda is a bank teller and active in a feminist movement” (TAF). Idąc po tej linii, formułuję hipotezę badawczą $\mathrm{H}_{\mathrm{o}}$ o postaci: „co najmniej $85 \%$ respondentów wybierze zdanie F, jako bardziej 
prawdopodobne niż zdanie $(\mathrm{T} \wedge \mathrm{F})$, a możliwość przeciwna zostanie, konsekwentnie, wybrana jedynie przez co najwyżej 15\% respondentów", którą to hipotezę zerową formułuję na podstawie wyników badań samych Kahnemana i Tversky’ego. Następnie przytaczam wyniki badań sondażowych wykonanych wśród studentów ( $\mathrm{N}^{\circ}$.1. i $\mathrm{N}^{\circ}$.2.), które częściowo odrzucają sformułowaną hipotezę, zgodnie z metodologią badań statystycznych. Na koniec prezentuję pewne rozumowanie wspierające osiągnięte rezultaty i formułuję krytyczne uwagi względem koncepcji heurystyk к т.

\section{SŁOWA KLUCZOWE}

eksperyment Kahnemana-Tversky'ego, heurystyki, interpretacje, problem Lindy, prawdopodobieństwo

\section{Bibliography}

Berendsen A., Hadlich S. J., van Amersfoort J., Looking at 'Linda': Is the Conjunction Fallacy Really a Fallacy?, draft, https://bacon.umcs.lublin.pl/ lukasik/wp-content/ uploads/2010/12/Looking-at-Linda.pdf (21.02.2019).

Chase R. H. V. M., Many Reasons or just One: How Response Mode Affects Reasoning in the Conjunction Problem, "Thinking \& Reasoning" 4 (1998) no. 4, p. 319-352.

Hertwig R., Gigerenzer G., The 'Conjunction Fallacy' Revisited: How Intelligent Inferences Look Like Reasoning Errors, "Journal of Behavioural Decision Making” 12 (1999), p. 275-305.

Maguire P., Moser P., Maguire R., Keane M. T., Why the Conjunction Effect Is Rarely a Fallacy: How Learning Influences Uncertainty and the Conjunction Rule, "Frontiers in Psychology" 9 (2018) no. 1011, doi.org/10.3389/fpsyg.2018.01011.

Messer W. S., Griggs R. A., Another Look at Linda, "Bulletin of the Psychonomic Society" 31 (1993) no. 3, p. 193-196.

Moro R., On the Nature of the Conjunction Fallacy, "Synthese" 171 (2009), p. 1-24.

Olszewski A., A Few Comments on the Linda Problem, "Organon F” 24 (2017), p. 184195.

Politzer G., Noveck I., Are Conjunction Rule Violations the Result of Conversational Rule Violations? "Journal of Psycholinguistic Research" 20 (1991), p. 83-103.

Tentori K., Bonini N., Osherson D., The Conjunction Fallacy: a Misunderstanding about Conjunction?, "Cognitive Science" 28 (2004), p. 467-477.

Tversky A., Kahneman D., Extensional versus Intuitive Reasoning: The Conjunction Fallacy in Probability Judgment, "Psychological Review" 90 (1983), p. 293-315. 